\title{
JUURNAL.RU
}

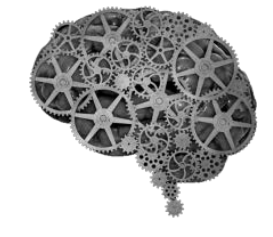

COMPANY GROUP "INTELLEKT"

\begin{abstract}
Тюльнина В.П., Рудакова А.Г. Национальный исследовательский технологический университет стали и сплавов Москва, Россия
\end{abstract}

doi: 10.18411/lj2016-3-82

\section{О роли мотивации в формировании профессиональной иноязычной компетенции у студентов в условиях неязыкового вуза}

Глобализация экономических и социальных процессов во всем мире, создание поликультурной среды и организация общеевропейского пространства вызывают все возрастающую роль иностранных языков как инструмента международного общения. Язык по своей природе всегда отличался интернациональностью, поэтому задача формирования у студентов иноязычной компетентности становится первоочередной как для технических, так и гуманитарных вузов. Несмотря на высокую социальную значимость свободного владения иностранными языками в современном обществе, проблема эффективности языкового обучения (в том числе в неязыковом вузе) не утрачивает свою актуальность. Более того, в настоящее время назрела необходимость формирования профессиональной иноязычной компетенции (а не просто коммуникативной компетенции), которая отражает цели и содержание профессионально ориентированного обучения в техническом вузе. Методическим эталоном должна стать профессионализация обучения, то есть моделирование уже в процессе обучения иностранному языку ситуаций речевого общения, ориентированных на профессиональную деятельность студентов. Иноязычная профессионализация подразумевает кроме того личностно-профессиональное становление и рост профессионального мастерства будущего специалиста в овладении иностранным языком. Под 
компетентностью в узком смысле понимается наличие у человека соответствующей компетенции, отражающей его личностное отношение к ней и к предмету деятельности [1]. Компетентность в целом представляет собой некий « комплексный человеческий ресурс», который позволяет эффективно взаимодействовать с окружающим миром в той или иной области благодаря наличию необходимых для этого взаимодействия компетенций [2]. В качестве обязательных компонентов компетентности выступают:

• положительная мотивация к проявлению компетентности;

- ценностно-смысловая подготовка к содержанию и результату деятельности;

- знания, лежащие в основе выбора способа реализации данной деятельности;

- умения, требующиеся для осуществления необходимых действий на базе имеющихся знаний [1].

Безусловно, в контексте образовательного процесса эффективность обучения во многом зависит от целого ряда субъективных факторов, приоритетное значение среди которых имеет мотивация. Речь идет о совокупности движущих сил, которые определяют выбор обучающимся предмета деятельности и обусловливают ее направленность. Для студента неязыкового вуза, на наш взгляд, ведущей мотивацией должна быть целенаправленная активность профессионального самоопределения. Другими словами, личностно-профессиональное самоопределение в процессе профессионального образования и есть содержание мотивационной структуры обучения студентов, поскольку важнейшей предпосылкой успеха учебной, а в последующем и профессиональной деятельности будущего специалиста является положительное отношение и устойчивый интерес к избранной профессии. Следовательно, эффективность изучения иностранного языка как обязательного компонента учебного процесса в вузе определяется функциональной значимостью иностранного языка в целостной структуре 
профессионально-личностного становления индивида, а также содержанием его профессиональной мотивации.

Однако практика показывает, что уровень языковой подготовки абитуриентов неязыкового вуза далеко не соответствует программным требованиям высшей школы. Объясняется это тем, что отношение к учебе в вузе на первых курсах продолжает носить, как и в школе, скорее формальный характер, то есть происходит некое накопление информации без ее дальнейшей реализации в соответствующих видах речевой деятельности, прежде всего, в говорении. Несмотря на наметившийся в последние годы явный сдвиг мотивации овладения иностранным языком в сторону ее повышения даже у студентов неязыковых вузов [3], проблема мотивации остается одной из ключевых проблем в психологии обучения, и формирование внутренней мотивации каждого студента является неотъемлемой частью эффективности учебного процесса. Решение этой задачи представляется отнюдь не простым при существующей небольшой сетке аудиторных занятий по иностранному языку, что, безусловно, порождает у студентов неуверенность в возможности использования иностранного языка в последующей профессиональной деятельности. При необеспеченной мотивации речевой деятельности на иностранном языке, которая формируется лишь при успешном участии в учебном процессе и осознании собственного прогресса, еще труднее говорить о формировании профессионально-ориентированной мотивации. Так как знания значительной части студентов, поступивших в неязыковый вуз, близки к нулевому уровню владения иностранным языком, преподавателю с большим трудом удается обеспечить формирование только базового уровня владения иностранным языком, да и то лишь по двум видам речевой деятельности чтению и устной речи (на уровне общей коммуникации).

Тем не менее, конечной целью обучения в неязыковом вузе является обучение профессиональной коммуникации. Следовательно, учебный процесс необходимо организовывать так, чтобы он обеспечивал овладение иностранным 
языком как на базовом, так и на профессиональном уровне. Проблема интенсификации учебного процесса может быть решена путем обеспечения активной и целенаправленной деятельности студентов под руководством преподавателя в аудитории, с одной стороны, и путем эффективной самостоятельной работы учащихся, с другой.

Формирование мотивации у первокурсников, приступающих к изучению иностранного языка в техническом вузе, также во многом зависит от их социально-психологической адаптации. Столкнувшись $\quad$ c первыми трудностями, студент часто испытывает чувство разочарования, и это существенно снижает успешность дальнейшего обучения иностранному языку. Появляется подавленное настроение и скука на занятиях. Одной из главных задач преподавателя является недопущение подобной ситуации, а если она все же возникла, необходимо ее преодолевать, повышая самооценку обучаемого, концентрируя его на результативность усилий, объясняя, что внутренним источником мотивации учебной деятельности каждого являются потребности обучающихся. От того, как эти потребности будут стимулироваться и удовлетворяться, зависит инициативность обучающихся в процессе обучения. Безусловно, преподаватель должен создать на занятии все условия для возникновения потребности в познавательной деятельности каждой личности. Одним из показателей смыслообразующей мотивации является осознание студентами практической, профессиональной значимости приобретаемых в вузе знаний, умений и навыков, ибо недопонимание этой значимости приводит к тому, что выпускники неязыковых вузов в своем большинстве испытывают трудности при чтении аутентичных профессионально ориентированных текстов, не говоря уже об умении составить деловое письмо или написать аннотацию профессиональной статьи. С другой стороны, не следует забывать и о том, что, будучи непрофильным учебным предметом , иностранный язык в условиях технического вуза не имеет как бы самостоятельного статуса, поэтому отношение студентов к этой дисциплине регулируется не профессиональными, 
а прагматическими мотивами: как сдать зачет или получить хорошую оценку по экзамену. Зачастую студенты не видят перспективы использования языка в будущей профессиональной деятельности, у них отсутствует ценностносмысловое отношение к изучению иностранного языка, что препятствует формированию мотивационной ориентации, а на более позднем этапе и профессиональной иноязычной компетенции. Анализ результатов исследования мотивации изучения иностранного языка в рамках НИТУ МИСиС свидетельствует о том, что иностранный язык в качестве профильной дисциплины (отделение лингвистики) приобретает предметно-деятельностное значение, а в качестве непрофильной дисциплины (все неязыковые специальности) имеет инструментальное значение (за небольшим исключением) как вспомогательный коммуникативный компонент будущей профессиональной деятельности.

В заключение хотелось бы отметить, что в силу огромных познавательных и коммуникативных возможностей и при правильном подходе иностранный язык может быть использован как исключительно важное средство подготовки студентов к эффективной профессиональной деятельности, стимулом для которой должна стать профессионально ориентированная мотивация. Психологический синтез выявленных мотивов позволяет в качестве гипотезы описать структуру профессиональной мотивации как конструкт-сочетание таких факторов как социальная значимость, познавательная самореализация и осознание профессионального самоопределения. Выделенные компоненты могут явиться важнейшими педагогическими «рычагами» воздействия для превращения начинающей учебной активности студента реальную профессиональную деятельность будущего конкурентоспособного специалиста 


\section{Литература}

1. Желкова О.А. Компетентность как основа деятельности специалиста./ О.А. Желкова. Научная жизнь.- 2008-.№ 4, с.77-79.

2. Мильруд Р.П. Компетентность в изучении языка./ Р.П.Мильруд. Иностранные языки в школе. - 2004 -№ 7, с.30- 37.

3. Тюльнина В.П., Рудакова А.Г. К проблеме обучения коммуникативной компетенции на иностранном языке в условиях неязыкового вуза./ Сборник научных статей «Обучение коммуникативной компетенции на иностранном языке. Издательство LAP LAMBERT Academic Publishing , 2014, S. 43. 